THURSDAY, OCTOBER 3I, I895.

\section{THE CENTENARY OF THE INSTITUTE OF FRANCE.}

$\mathrm{F}$ ROM the brief telegraphic reports published in some of the English newspapers, readers in this country may have observed that the hundredth anniversary of the foundation of the Institut de France was celebrated last week in Paris. These reports, however, convey but a feeble impression of the real character of the celebration. The Institute is an establishment of which Frenchmen of all classes and of every shade of political opinion are justly proud. They look on it as a living embodiment of the culture and intellectual power of France. It stands above and beyond politics. Forms of Government may come and go ; kings, emperors, and republics may arise, flourish, and disappear. But the Institute remains unshaken, quietly pursuing its career, and sustaining with marvellous success the intellectual glory of the nation. No wonder, then, that amid the turmoil of parties, the strifes of Parliament, and the endless changes of Ministries, many men turn to the Institute as the only stable institution, which royalists, republicans, socialists, and anarchists seen to be alike agreed in respecting.

That Republicans especially should show an interest in this institution was natural. It was founded a hundred years ago during the first Republic. The idea of restoring the old Academies and combining them into one central institution was carried out by the Republican Convention, with the openly professed intention of promoting the literary, artistic and scientific labours which should best contribute to the general benefit and glory of the Republic. After all the transformations of the last hundred years, a Republican form of government is once more in power. It was only fitting, therefore, that the State, by its highest officials, should manifest its interest in this, the oldest and most illustrious child of the Revolution, by taking an active and prominent part in the Centenary of its existence.

An Englishman privileged to be present at the celebration could not fail to be struck by various features in it that stood out in marked contrast to anything that would have been possible in his own country. In the first place, of course, the Institute itself is unique, in the wide range of subjects with which it is concerned. We have many admirable learned societies at home, from the Royal Society downwards, and so far as scientific progress is concerned, they are possibly of at least as great service as any Academy of Sciences in the world. We have likewise our Royal Academy of the fine arts, which may, it is to be hoped, hold its own against any foreign competitor. We have, however, nothing that corresponds to the French Institute, and the question has often been discussed whether the creation of such an Institute amongst us would be possible or desirable. But what especially strikes a stranger at such a gathering as that of last week in Paris, is the catholicity of view which led to the union under one organisation of so vast a range of human culture and faculty. Prosewriters, poets, dramatists, antiquaries, mathematicians, physicists, astronomers, geographers, engineers, NO. I 3.57, VOL. 5.2] chemists, mineralogists, geologists, botanists, anatomists, zoologists, physicians, surgeons, painters, sculptors, architects, engravers, musicians, writers on philosophy, morals, law, political economy, and history-all meet as in a common home under the dome of the Institute on the banks of the Seine. Each of the five Academies has its own sphere of activity and its own independent organisation. But they confer mutual strength and dignity on each other by the common tie that binds them together as the Institute of France. And one cannot help feeling that in a country liable to such political vicissitudes as France has gone through during the last hundred years, it has been of unspeakably great advantage to the stability and progress of all the arts and sciences which elevate a people, that this solidarity of intellectual effort should have been established at the beginning of the long succession of political troubles.

Another feature which impressed a native of this country was the direct, hearty and effective part which the highest functionaries in the State played in the chief events of the celebration. The President of the Republic himself received the foreign members and correspondants one morning at the Elysée, shaking hands with each, and stopping every now and then to say some few appropriate words to one whose name or whose work was known to him. The whole ceremony was as simple and natural as it was pleasant. M. Faure likewise presided at the opening meeting at the Sorbonne; and on Friday evening he held a brilliant reception, to which all the members and correspondants of the Institute were invited, with their wives, together with a large assemblage of other guests, including the Ministry, the Diplomatic Corps, and representatives of the chief departments and institutions. In short, everything which the head of the State could do to testify officially the pride and interest of France in her Institute was done simply and heartily. One felt that the President, kindly and gracious as he was personally, represented a national feeling which would have demanded expression no matter what form of Government had been in existence, or what political party had been in power.

Nor was the action of the President the only manifestation of official interest in the celebration. The Prime Minister, the Ministers for Foreign Affairs, War, Marine, Public Instruction, and others found time to spend an hour or two at one or other of the gatherings. The Minister for Public Instruction, M. Poincaré, indeed, multiplied himself in the most astonishing way. Having the official control of the department under which such organisations as the Institute are placed, he evidently considered it to be his duty, as it seemed certainly to be a pleasure to him, to attend every gathering where his presence could testify the sympathy of the Government with the Institute and its objects. At one time he was to be seen at the Ministry of Public Instruction holding a reception of all the academicians and correspondants, with their wives, and a large company of representative men from outside. At another time he was on the platform beside the President, making a vigorous speech, and conveying to the Institute the appreciation which he and his colleagues had of the work which the various Academies had accomplished. Again he was in his place presiding at the banquet given to the Institute, ready once 
more with eloquent words to wish prosperity to literature, art, and science. And as if all this were not enough in the midst of his other busy official engagements, we found him just after breakfast at the unveiling of the Meissonier statue in the Louvre Gardens, where he made an admirable speech, summing up the characters of Meissonier's work.

An Englishman might be forgiven if he ventured to express openly his opinion that such things as these could not, or at least would not, be done in his own country. We suppose our Vice-President of the Council is the Minister who most nearly corresponds here to the Minister of Public Instruction in France. But when had we ever a Vice-President who thought it worth his while to show, outside of his official duties, so much active interest in the cause of science, art, and literature?

While this recognition from the State and its functionaries was extended to the Institute, the latter showed in several ways how well it realised its representative character as the outward symbol of the higher intellectual progress of France. One was especially impressed by the way this feeling was exhibited at the opening gathering in the great hall of the new Sorbonne. Behind the academicians and correspondants, the best seats in the building were allocated to representatives of education, law, justice, \&c. The chief schools and colleges had places allotted to them, legibly marked out by large labels affixed to them. Lawyers, judges, and professors came in their robes to take part in the proceedings. Every section of the programme appeared to have been most carefully thought out. There was a well-trained orchestra, which began by playing a composition of the first composer who became a member of the Institute of France, and afterwards gave a fragment of Mors et Vita, by Gounod-the last composer who had passed away from the Academy of the Beaux-Arts. Good care, indeed, was taken in the celebrations to show that music and the drama were included within the range of the Institute's activities. An afternoon "gala" performance at the Theâtre Français included parts of Corneille's Cid and Molière's École des Femmes and Femmes Savantes, wherein the chief members of this incomparable company showed once more what perfect acting should be.

Lastly, a stranger could not but be pleased with the numerous facilities offered to him to meet his old friends, and to make new ones. At the evening receptions and dinners, at the daylight gatherings in the Institute buildings, and in the foyer of the Théâtre Français, but most of all in the excursion to Chantilly, and the rambles through the rooms and grounds of that princely chateau, he had opportunities of seeing everybody that he wished to converse with. No one who went to Chantilly will be likely to forget the success of that concluding day of the proceedings - the autumnal woods with their long vistas, the magnificent castle, the endless treasures of art and literature within the rooms, but above all, and as the centre and soul of the whole scene, the figure of the Duke d'Aumale, who has gifted all that estate to the Institute. Sitting in his bath-chair wrapped up in black velvet, hardly recovered from his last attack of gout, he showed himself the most vivacious talker in the company, shaking hands with his guests, discoursing to them of pictures, travel, and incidents of his life with the urbanity and dignity of the old grand seigneur.

$$
\text { No. } 1357 \text {, voL. } 52 \text { ] }
$$

There was one special source of gratification to English visitors in the remarkable band of men who went tc represent Great Britain at the Centenary. The French members of the Institute seemed to feel the compliment paid to them by the attendance of so many illustrious men of science, literature and art. And the strength of the English contingent drew forth the admiration of visitors from other countries. It was pleasant, in these days of political rivalry, to see human culture linking men in a brotherhood which stands above nationality and politics, and more especially to note that nearly the whole of the Englishmen who have been so generously recognised by the Institute of France should have attended its Centenary.

\section{THE GOLD MINES OF THE RAND.}

The Gold Mines of the Rund; being a Description of the Mining Industry of Witwatersrand, South African

Republic. By F. H. Hatch and J. A. Chalmers.

(London : Macmillan and Co., 1895.)

A FRICA is proverbially a land of surprises. It is not likely, however, that more startling surprises can be in store than those witnessed by the present generation. We have seen a great city spring up, in what, before the discovery of gold in the Witwatersrand, was a desert, a city with over eighty mines, the workings of which extend east and west from Johannesburg for $45^{\circ} 8$ miles. The mines have been worked with regularity, and the augmentation of dividends has attracted the attention of capitalists in all parts of the globe, resulting in the Russian Government commissioning Mr. Kitaeff to report on the gold-field, and in the Prussian Government despatching Mr. Schmeisser for the same purpose. The output of gold from the Witwatersrand has risen from 23,000 ozs. in 1887 to $2,023,198$ ozs., valued at nearly $£ 7, \infty 00,000$, in 1894 , whilst the return for the first nine months of the current year was $1,711,337$ ozs. The Transvaal now produces one-fifth of the world's supply. It is calculated that at the present rate of progress the output of the Witwatersrand mines will have reached by the end of the century a value of $£ 20,000, \infty 00$.

To the already ample literature relating to the Transvaal gold mines, this handsome and profusely illustrated volume of three hundred large octavo pages is the most valuable contribution that has yet appeared. The authors possess special qualifications for the important task they have undertaken. Mr. J. A. Chalmers is an Associate of the Royal School of Mines, and his brilliant career as a student has been followed by many years successful practice as a mining engineer in South Africa; whilst Dr. F. H. Hatch's scientific attainments and literary skill are well known from his important petrographical researches carried out previously to his retirement in 1892 from the Geological Survey of England and Wales, and from his useful manuals on mineralogy and petrology.

The authors divide their subject-matter into twelve chapters. The first deals with the history of the gold discoveries and of the development of the mining industry, whilst the subsequent chapters deal respectively with the geology, the auriferous conglomerates, the 